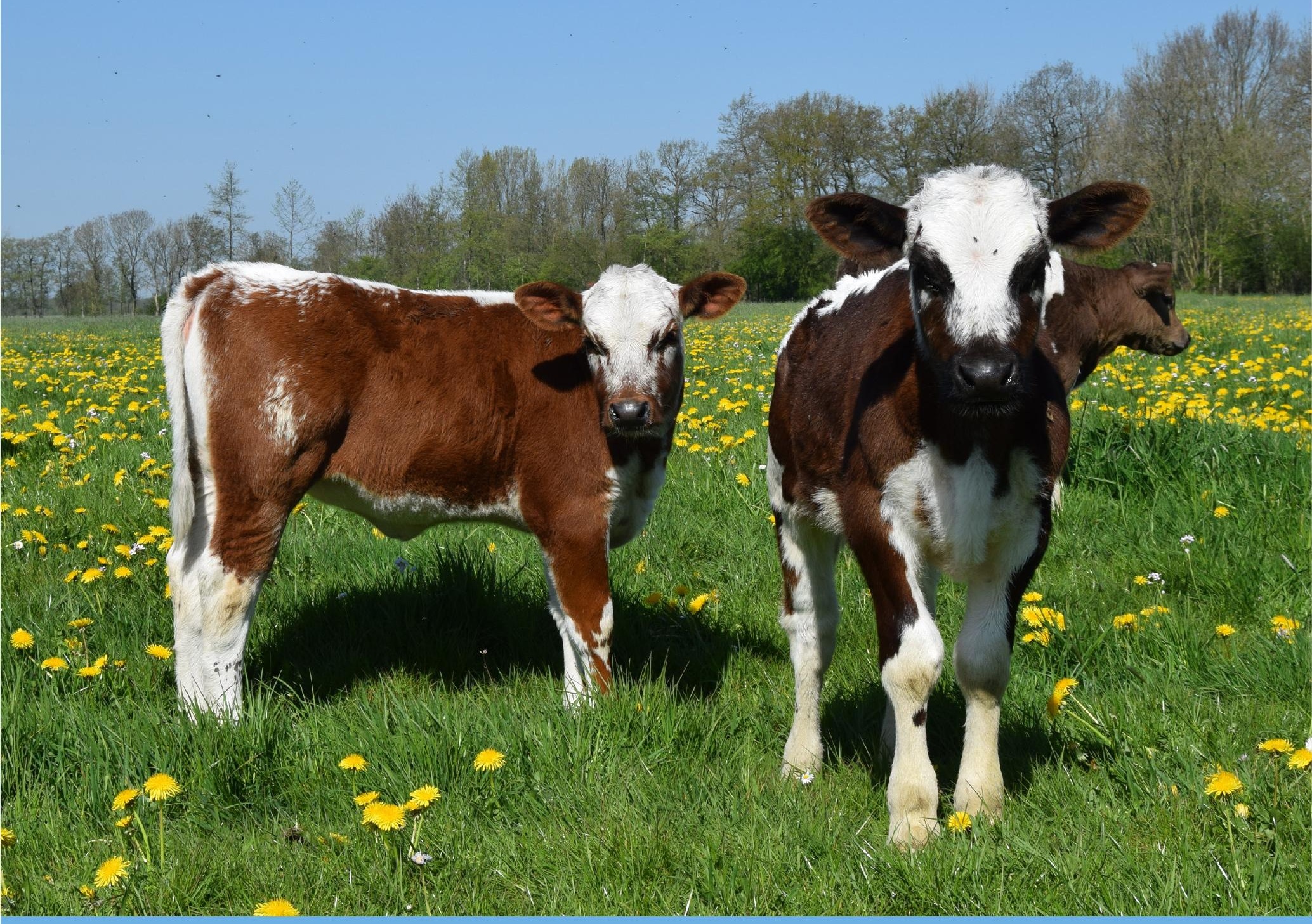

\title{
Unieke genetische variatie in een bijzondere Nederlandse rundveestapel met zeldzame kleuren en aftekeningen
}





\section{Unieke genetische variatie in een bijzondere Nederlandse rundveestapel met zeldzame kleuren en aftekeningen}

Anouk Schurink ${ }^{1}$, Jack Windig ${ }^{1}$, Henk Sulkers ${ }^{1}$, Ina Hulsegge ${ }^{1}$, Kor Oldenbroek ${ }^{1}$

${ }^{1}$ Centre for Genetic Resources, the Netherlands (CGN) van Wageningen University \& Research

Dit onderzoek is uitgevoerd door CGN, in opdracht van en gefinancierd door het ministerie van Landbouw, Natuur en Voedselkwaliteit (LNV), in het kader van WOT-03 Genetische Bronnen (projectnummer WOT-03-003-056) 
Schurink, A., J.J. Windig, H. Sulkers, B. Hulsegge, J.K. Oldenbroek, 2019. Unieke genetische variatie in een bijzondere Nederlandse rundveestapel met zeldzame kleuren en aftekeningen. Centre for Genetic Resources, the Netherlands (CGN), Wageningen University \& Research, CGN rapport 43. 29 blz.; 6 fig.; 8 tab.; 5 ref.

Samenvatting NL De veestapel van familie van der Veen bestaat uit ongeveer 40 runderen met de witrik aftekening en de zeldzame kleuren vaal en blauw. Zeldzame kleuren en aftekening die door jarenlange gerichte fokkerij bij elkaar zijn gebracht én in stand zijn gehouden. De bijzondere veestapel van beperkte omvang heeft daarmee unieke combinaties van zeldzame allelen en genotypes. Omdat er geen stamboekgegevens van de runderen zijn, is de genetische achtergrond van de runderen met behulp van DNA onderzoek in kaart gebracht. De veestapel van familie van der Veen clustert niet samen met een enkel oorspronkelijk Nederlands ras en omvat unieke combinaties van rassen en genetische diversiteit. De geobserveerde zeldzame kleuren werden middels DNA onderzoek geverifieerd. Het DNA kwam, op één rund na, overeen met de geobserveerde kleur voor de basiskleur rood/zwart en de aan- of afwezigheid van de vaal kleur. Voor de aftekening witrik en de kleuren blauw en bont konden geen harde uitspraken gedaan worden omdat de daadwerkelijke mutatie niet gegenotypeerd was. Op basis van DNA zijn alle bekende moeder-nakomeling relaties geverifieerd en relaties op basis van DNA inzichtelijk gemaakt. De veestapel bevat unieke combinaties van zeldzame kleuren en aftekeningen en de runderen zijn genetisch uniek. Het is daarom van belang dat de genetische diversiteit van deze veestapel behouden blijft.

Summary UK The herd of van der Veen family consists of about 40 cattle with the color-sided pattern and the rare diluted and roan color. Rare colors and pattern that are brought together through years of targeted breeding and conservation. The exclusive herd of small size therefore has unique combinations of rare alleles and genotypes. Because there are no registration papers present, the genetic make-up of this herd was investigated through DNA analysis. The herd of van der Veen family does not cluster with any one of the local Dutch cattle breeds and therefore consists of unique combinations of breeds and genetic diversity. The observed rare colors were verified through DNA analysis. The DNA, expect for one individual, matched the observed color for red/black and the absence or presence of the diluted color. For the color-sided pattern, and the spotted and roan color no conclusions could be made as the mutation itself was not genotyped. Based on DNA all known mother-offspring relationships were verified and DNA also provided insights concerning other relationships between the individuals. The herd consists of unique combinations of rare colors and pattern and the animals are genetically unique. It is therefore important to conserve the genetic diversity within this herd.

Dit rapport is gratis te downloaden op https://doi.org/10.18174/476297 of op www.wur.nl/cgn onder CGN rapporten.

(C) 2019 Centre for Genetic Resources, the Netherlands (CGN), Wageningen University \& Research Ecgn@wur.nl

Wageningen University \& Research aanvaardt geen aansprakelijkheid voor eventuele schade voortvloeiend uit het gebruik van de resultaten van dit onderzoek of de toepassing van de adviezen.

Alle rechten voorbehouden. Niets uit deze uitgave mag worden vermenigvuldigd en/of openbaar gemaakt worden door middel van druk, fotokopie, microfilm of op welke wijze dan ook zonder voorafgaande toestemming van de uitgever of auteur.

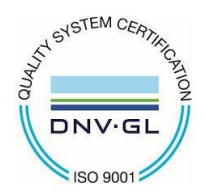

De certificering volgens ISO 9001 onderstreept ons kwaliteitsniveau. 


\section{Inhoud}

$\begin{array}{ll}\text { Woord vooraf } & 5\end{array}$

$\begin{array}{ll}\text { Samenvatting } & 7\end{array}$

1

$\begin{array}{ll}\text { Introductie } & 9\end{array}$

1.1 Achtergrond en doel 9

1.2 Werkwijze 9

$\begin{array}{lll}1.3 & \text { Beschikbaar onderzoeksmateriaal } & 10\end{array}$

2

$\begin{array}{ll}\text { Verwantschap met Nederlandse runderrassen } & 11\end{array}$

2.1 Verwantschap tussen runderen 11

2.2 Indeling naar raspercentage(s) 11

2.2.1 Uitlichting individuele runderen $\quad 12$

2.2.2 Aandeel Fries-Hollands - zwart én rood 12

2.3 Samenvatting bevindingen verwantschap met Nederlandse runderrassen $\quad 13$

$\begin{array}{lll}3.1 & \text { Kleuren aanwezig in de veestapel } & 14\end{array}$

3.2 Genetische merkers die bijdragen aan kleurvererving $\quad 14$

3.3 Relaties tussen genotypes (DNA) en fenotypes (kleur) 15

3.4 Vergelijking tussen geobserveerde kleur, verwacht en geobserveerd genotype per $\begin{array}{ll}\text { rund } & 20\end{array}$

3.5 Samenvatting bevindingen kleurvererving in de veestapel 21

4.1 Het principe van tegengestelde homozygoten $\quad 22$

4.2 Ouder-nakomeling relaties $\quad 23$

$\begin{array}{lll}4.3 & \text { Overige relaties } & 24\end{array}$

4.4 Samenvatting bevindingen vaststellen familiebanden $\quad 25$

$\begin{array}{ll}\text { Literatuur } & 26\end{array}$

Bijlage 1 Individuele vergelijking tussen geobserveerde kleur, verwacht en geobserveerd genotype per rund 



\section{Woord vooraf}

Het Centrum voor Genetische Bronnen Nederland (CGN) geeft op aanvraag technische ondersteuning aan rasverenigingen en stamboeken over het behoud van genetische diversiteit en duurzame ontwikkeling van rassen die levend bewaard en benut worden. Daarbij ligt de nadruk op de ontwikkeling en evaluatie van fokstrategieën, waarbij enerzijds de genetische diversiteit van het ras behouden wordt en anderzijds het ras ook beter benut kan worden. Het CGN bepaalt in overleg met bovengenoemde organisaties welke dieren in de genenbank opgeslagen moeten worden en welke dieren uit de genenbank opnieuw ingezet worden om de genetische diversiteit van de levende populatie te verbreden. Deze keuzes worden gemaakt op basis van afstammingsgegevens, maar zo mogelijk worden ook DNA analyses hiervoor gebruikt.

Het CGN bedankt de familie van der Veen van harte voor hun medewerking, en de Stichting Roodbont Fries Vee voor hun vraagstelling en financiële bijdrage aan het onderzoek dat resulteerde in het rapport. De veestapel van familie van der Veen bevat unieke combinaties van zeldzame kleuren en aftekeningen en de runderen zijn genetisch uniek. Het is daarom van belang dat de genetische diversiteit van deze veestapel behouden blijft. Met het oog hierop zal sperma van de aanwezige stieren worden veiliggesteld in de genenbank. 


\section{Samenvatting}

De veestapel van familie van der Veen bestaat uit ongeveer 40 runderen met de witrik aftekening en de bijzondere kleuren vaal en blauw. Dit zijn zeldzame kleuren en aftekening die door jarenlange gerichte fokkerij bij elkaar zijn gebracht en hebben geresulteerd in een bijzondere veestapel van beperkte omvang met unieke combinaties van zeldzame allelen en genotypes. De afstamming van de runderen wordt bijgehouden door familie van der Veen, maar de runderen zijn nog niet ingeschreven in een stamboek. Met een DNA analyse op basis van genotypes van alle runderen zijn drie onderzoeksvragen beantwoord.

Met welke oorspronkelijke Nederlandse rassen is de veestapel van familie van der Veen verwant? Verwachting vanuit de geschiedenis van de veestapel van familie van der Veen is dat zowel FriesHollands - zwart én rood hebben bijgedragen. De invloed van deze rassen varieert per rund, en is gemiddeld $27,5 \%$. Daarnaast laten de resultaten zien dat de veestapel van familie van der Veen niet samen clustert met een enkel oorspronkelijk Nederlands ras. De veestapel van familie van der Veen omvat een unieke combinatie van genetische diversiteit.

Is het genotype vast te stellen voor de verschillende loci voor de diverse kleurvarianten? Het verwachte genotype op basis van de geobserveerde kleur kwam, op één rund na, overeen met de geobserveerde genotypering voor de basiskleur rood/zwart en de aan- of afwezigheid van de vaal kleur. Voor deze kleuren kon de daadwerkelijke mutatie die de kleur veroorzaakt, bekeken worden. Voor de kleuren witrik, bont en blauw konden er geen harde uitspraken worden gedaan, omdat de daadwerkelijke mutatie niet gegenotypeerd was. Door gerichte fokkerij zijn deze zeldzame kleuren en aftekening bij elkaar gebracht en behouden gebleven. De bijzondere veestapel van beperkte omvang heeft unieke combinaties van zeldzame allelen en genotypes.

Welke familiebanden tussen welke runderen kunnen worden geïdentificeerd?

Op basis van DNA zijn alle moeder-nakomeling combinaties die bekend zijn, geïdentificeerd en daarmee zijn de diverse moederlijnen aanwezig in de veestapel van familie van der Veen geverifieerd met DNA. Op basis van DNA zijn ook overige relaties tussen de runderen in kaart gebracht.

\section{Geformuleerde advies}

Conservering van de veestapel wordt geadviseerd in verband met unieke combinaties van allelen, de aanwezige genetische diversiteit, en ruime aanwezigheid én combinaties van zeldzame kleuren en aftekeningen. Ondersteuning vanuit Stichting "De Witrik", de Vereniging voor de fokkerij van het Fries-Holands rundveeras en Stichting Roodbont FriesVee is gewenst om deze veestapel in stand te houden, evenals opslag van genetisch materiaal (sperma en embryo's) in de genenbank. 


\section{$1 \quad$ Introductie}

Hoofdstuk 1 geeft een beschrijving van de achtergrond en het doel van het onderzoek, de gevolgde werkwijze en het beschikbare materiaal op basis waarvan het onderzoek is uitgevoerd.

\subsection{Achtergrond en doel}

De veestapel van familie van der Veen bestaat uit ongeveer 40 runderen met de witrik aftekening. De veestapel is opgebouwd met Friese roodbonte en zwartbonte runderen, waarin bewust de erfelijke factoren voor witrik, vaal en blauw zijn ingebracht (zie Figuur 1.1). Zeldzame kleuren en aftekening die door gerichte fokkerij bij elkaar zijn gebracht en resulteren in unieke combinaties van allelen en genotypes in een bijzondere veestapel van beperkte omvang. De afstamming van de runderen wordt bijgehouden door familie van der Veen, maar de runderen zijn nog niet ingeschreven in een stamboek. Met een DNA analyse op basis van genotypes van alle runderen wordt getracht in een onderzoek drie onderzoeksvragen te beantwoorden:

1. Met welke oorspronkelijke Nederlandse rassen is de veestapel van van der Veen verwant?

2. Is het genotype (homozygoot-heterozygoot) vast te stellen voor de verschillende loci voor de kleurvarianten: zwart/rood, bont, witrik, vaal en blauw?

3. Welke familiebanden tussen welke runderen kunnen worden geïdentificeerd?
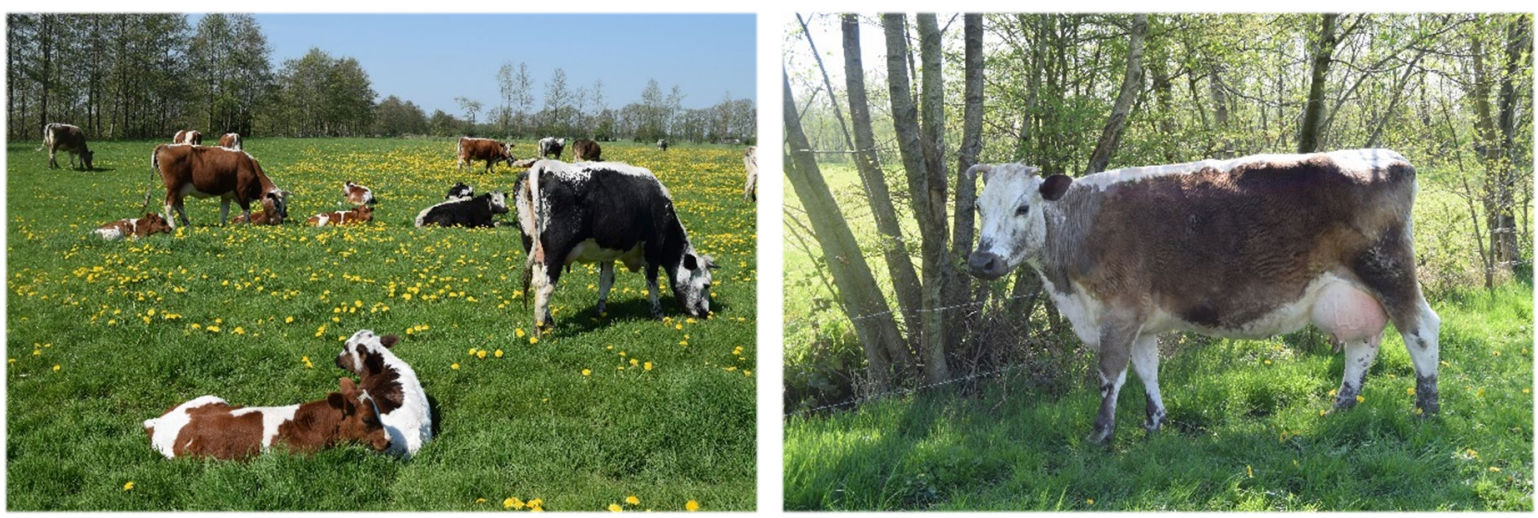

Figuur 1.1 Links: de huidige kudde; rechts: één van de huidige koeien. Foto's: Pytsje van der Veen.

Elke onderzoeksvraag wordt in een apart hoofdstuk uitgewerkt. Met het zogeheten genomisch onderzoek zal er meer inzicht worden verkregen in de (genetische) karakteristieken van de runderen in deze veestapel. Deze inzichten zouden kunnen leiden tot verzameling van materiaal voor ex situ conservering om bijzondere genetische diversiteit te kunnen veiligstellen voor de toekomst.

\subsection{Werkwijze}

Het CGN heeft samen met familie van der Veen de haarwortelmonsters van alle runderen genomen. Van de runderen werd het levensnummer genoteerd. De monsters zijn voor DNA-onderzoek (genotyperen van 53.215 genetische merkers genaamd SNPs) naar de Universiteit van Luik in België gegaan. De uitkomsten van de onderzoeken (genotypes) zijn gebruikt in de analyses die de drie onderzoeksvragen uitwerkt en rapporteert. 


\subsection{Beschikbaar onderzoeksmateriaal}

Haarmonsters van 47 runderen zijn verzonden naar de Universiteit van Luik in België. Uiteindelijk waren de genotypes van 52.646 SNPs van 47 runderen van voldoende kwaliteit om de analyses op uit te voeren (call-rate $\geq 90 \%$ ). Een beschrijving van de dataset staat weergegeven in Tabel 1.1.

Tabel 1.1 Beschrijving van de dataset - geboortejaar en geslacht van de 47 onderzochte runderen van de veestapel van familie van der Veen.

\begin{tabular}{crr} 
Kenmerk & Aantal runderen & Percentage \\
Geboortejaar & 4 & \\
\hline 2005 & 2 & $8,5 \%$ \\
\hline 2007 & 1 & $2,3 \%$ \\
\hline 2009 & 2 & $4,3 \%$ \\
\hline 2010 & 2 & $4,3 \%$ \\
\hline 2011 & 6 & $12,8 \%$ \\
\hline 2012 & 3 & $6,4 \%$ \\
\hline 2013 & 1 & $2,1 \%$ \\
\hline 2014 & 13 & $27,6 \%$ \\
\hline 2016 & 13 & $27,6 \%$ \\
\hline 2017 & & \\
\hline Geslacht & 4 & $8,5 \%$ \\
\hline Mannelijk & 43 & $91,5 \%$ \\
\hline Vrouwelijk & \multicolumn{2}{c}{}
\end{tabular}

Aanvullend werden 24 mutaties gegenotypeerd die een bepaalde variatie in kleur teweegbrengen. Het genotyperen van deze mutaties was succesvol voor 46 runderen.

Om vast te stellen met welke oorspronkelijke Nederlandse rassen de veestapel van familie van der Veen verwant is, is er gebruik gemaakt van reeds beschikbare genotypes van Brandrode, Fries Hollands - zwart, Groninger Blaarkop, Holstein Friesian, Lakenvelder, Maas-Rijn-IJssel en Roodbont Fries vee runderen. Materiaal van deze runderen betrof genotypes van stieren uit de genenbank als ook van reeds eerder uitgevoerde wetenschappelijke onderzoeken (Hulsegge et al., 2019). Daarnaast waren de genotypes ook verkregen uit DNA van haarmonsters van verschillende bedrijven in Nederland. Monsters van de Holstein Friesian runderen waren afkomstig van Dairy Campus. Verder is gebruik gemaakt van materiaal van Angler runderen omdat runderen van dit ras voorheen zijn ingezet in de fokkerij van familie van der Veen. Genotypes van Angler runderen werden verkregen via der Rinderzucht Schleswig-Holstein eG en VIT in Duitsland. 


\section{Verwantschap met Nederlandse runderrassen}

Met behulp van DNA kan vastgesteld worden hoe nauw verwant bepaalde individuen en ook rassen zijn. In dit hoofdstuk beantwoorden we de volgende onderzoeksvraag: met welke oorspronkelijke Nederlandse rassen is de veestapel van familie van der Veen verwant?

\subsection{Verwantschap tussen runderen}

De verwantschap van de 47 runderen ten opzichte van voornamelijk oorspronkelijke Nederlandse runderrassen is vastgesteld met behulp van een PCA grafiek. Daarbij worden de genotypes van alle runderen onderling vergeleken en de variatie die aanwezig is in de dataset opgedeeld in principale componenten (PC). PC1 verklaart de meeste variatie, gevolgd door PC2, PC3, etc. Elk stipje in de grafiek is een rund; hoe dichter bij elkaar twee stipjes liggen, hoe meer verwant deze twee runderen zijn.

De PCA berekeningen en grafieken zijn gemaakt met behulp van prcomp functie in R software.

De PCA grafieken laten zien dat de veestapel van familie van der Veen niet samen clustert met één van de oorspronkelijke Nederlandse runderrassen (zie Figuur 2.1) en is daarmee niet nauw verwant aan één van de oorspronkelijke Nederlandse runderrassen. Gemiddeld genomen is de verwantschap met Holstein-Friesian, MRIJ en Groninger Blaarkop beperkt. Inzetten op het verzamelen van sperma van stieren aanwezig in deze veestapel en embryo's is een gewenste volgende stap.
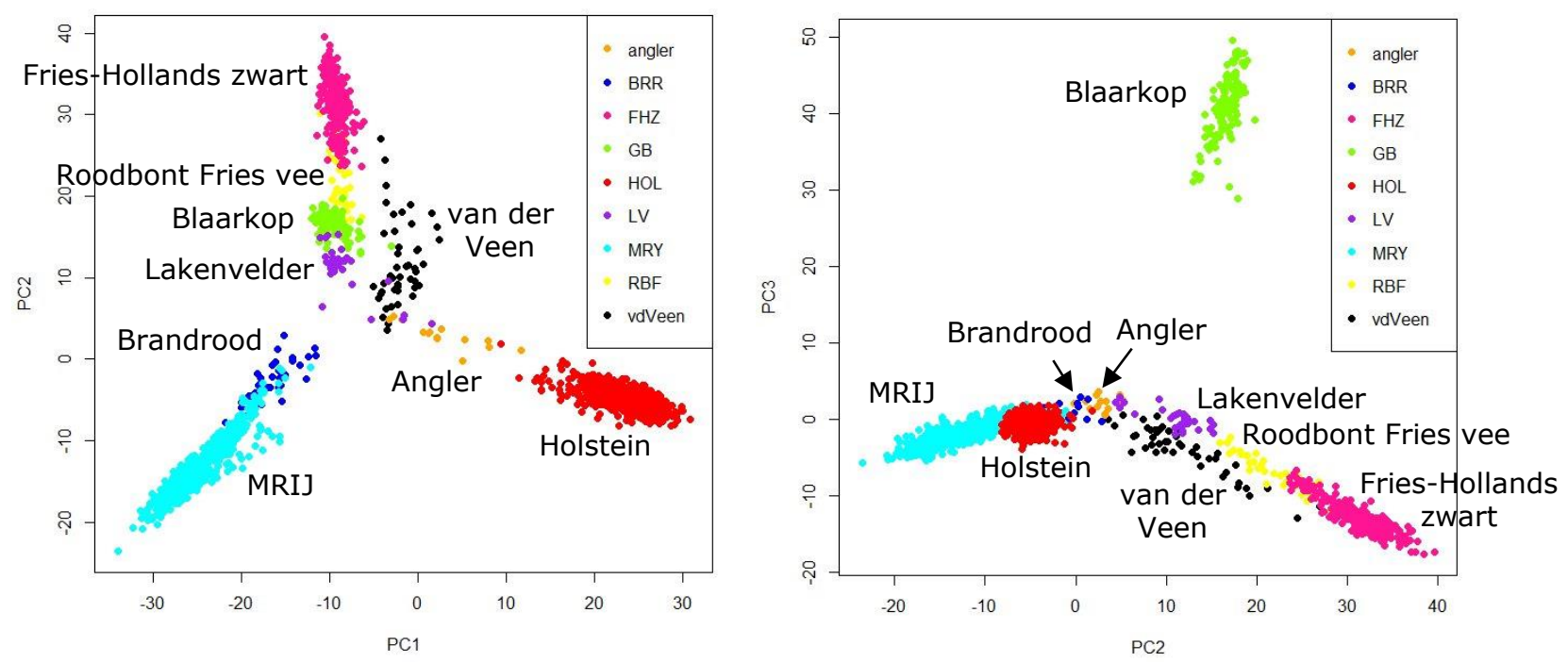

Figuur 2.1 PCA grafieken met principale componenten $(P C)$ 1, 2 en 3 waarbij de verwantschap tussen alle runderen wordt weergegeven. angler $=$ Angler rund, $B R R=$ Brandrode rund, FHZ $=$ FriesHollands - zwart, GB = Groninger Blaarkop, $H O L=$ Holstein Friesian, $L V=$ Lakenvelder, MRY = MaasRijn-IJssel vee, $R B F=$ Roodbont Fries vee, vdVeen = veestapel van familie van der Veen.

\subsection{Indeling naar raspercentage(s)}

Aan de hand van de genotypes werd vastgesteld wat de raspercentages van elk ras voor een rund uit de veestapel van familie van der Veen was. Voor elk rund wordt berekend voor hoeveel procent het DNA afkomstig is van de ras(sen) in de (referentie)dataset. Deze analyse werd uitgevoerd met het 
programma STRUCTURE (versie 2.3.4; Pritchard et al., 2000). De resultaten staan weergegeven in Figuur 2.2. Elk staafje is één rund. Per rund wordt aangegeven wat het raspercentage voor elk ras bedraagt. Is een raspercentage hoog, dan betekent dit dat het DNA van het rund dat onderzocht wordt sterke overeenkomsten heeft met de runderen van dat betreffende ras waarvan reeds eerder het DNA was onderzocht (de referentiepopulatie van het betreffende ras). Middels het onderzoek uitgevoerd voor het project naar raszuiverheid van runderen op basis van DNA, is vastgesteld dat wanneer een rund $77,5 \%$ of meer raspercentage van één specifiek ras heeft, dit rund kan worden omgeschreven als raszuiver voor het betreffende ras.

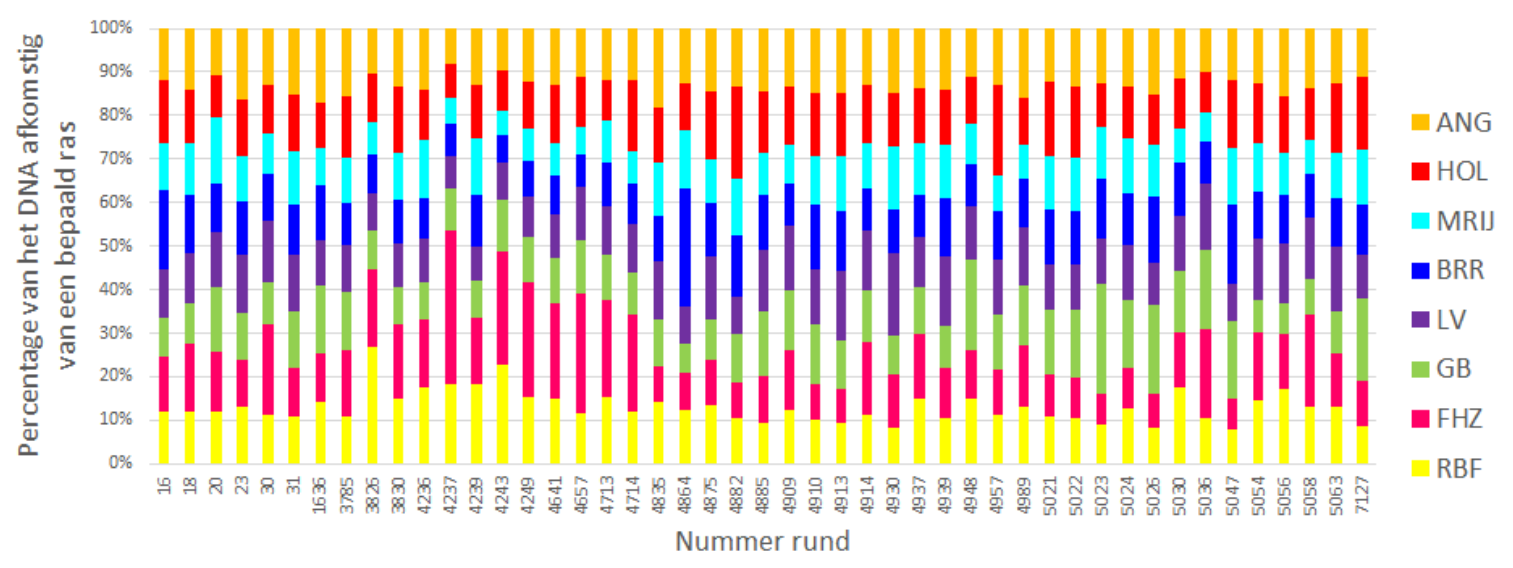

Figuur 2.2 Resultaten van de STRUCTURE analyse waarbij voor elk individueel rund het raspercentage voor elk ras wordt weergegeven (volgorde in de legenda, is ook de volgorde in de grafiek). $A N G=$ Angler rund, $B R R=$ Brandrode rund, $F H Z=$ Fries-Hollands - zwart, GB = Groninger Blaarkop, $H O L=$ Holstein Friesian, $L V=$ Lakenvelder, MRIJ = Maas-Rijn-IJssel vee, $R B F=$ Roodbont Fries vee.

De analyse toont aan dat de veestapel van familie van der Veen een unieke combinatie van genetisch materiaal omvat: gemiddeld per rund 13,1\% Roodbont Fries vee, 14,5\% Fries-Hollands, 12,3\% Groninger Blaarkop, 11,9\% Lakenvelder, 11,6\% Brandrood, 10,4\% MRIJ, 13,0\% Holstein Friesian en $13,2 \%$ Angler.

\subsubsection{Uitlichting individuele runderen}

Voor de veestapel van familie van der Veen had geen enkel rund meer dan 77,5\% raspercentage voor Fries Hollands - zwart en Roodbont Fries vee bij elkaar opgeteld. Volgens het protocol voor vaststelling raszuiverheid middels DNA zou geen rund uit de veestapel van familie van der Veen in aanmerking komen om als raszuiver te worden ingeschreven in het stamboek.

De moeder van Diana 5 (4714) is aangekocht. Familie van der Veen gaf aan dat er naar verwachting MRIJ en/of HF bloed aanwezig kan zijn in deze koe. De analyses op basis van DNA toonde inderdaad aan dat er een redelijk aandeel HF bloed aanwezig is (zie Figuur 2.2).

Familie van der Veen gaf aan dat in de Andrieske lijn MRIJ bloed aanwezig is. De analyses op basis van DNA toont inderdaad aan dat er een aandeel MRIJ bloed aanwezig is (31, 4930 en 5021 in Figuur 2.2).

Daarnaast gaf familie van der Veen aan dat in Verhildersum Femke MRIJ bloed aanwezig zou kunnen zijn. De analyses op basis van DNA toont aan dat er MRIJ bloed aanwezig is (3785 in Figuur 2.2).

\subsubsection{Aandeel Fries-Hollands - zwart én rood}

Verwachting vanuit de geschiedenis van de veestapel van familie van der Veen is dat zowel FriesHollands - zwart én rood hebben bijgedragen. Figuur 2.3 focust alleen op het opgetelde raspercentage voor deze twee populaties. 
Het raspercentage voor Fries-Hollands - zwart én rood bij elkaar opgeteld, varieert van 14,9\% tot $53,5 \%$ en bedraagt gemiddeld $27,5 \%$ wanneer de veestapel van familie van der Veen wordt vergeleken met de referentiepopulaties van deze rassen. De referentiepopulatie van rood is qua aantallen nog vrij beperkt en omvat daarmee waarschijnlijk niet de gehele diversiteit aanwezig in het ras. Daarnaast bestaat de mogelijkheid dat de lijnen die de familie van der Veen in hun fokkerij heeft gebruikt, niet meer aanwezig zijn in de huidige foklijnen. Hierdoor kan het raspercentage voor FriesHollands - zwart én rood mogelijk wat lager zijn uitgevallen dan verwacht.

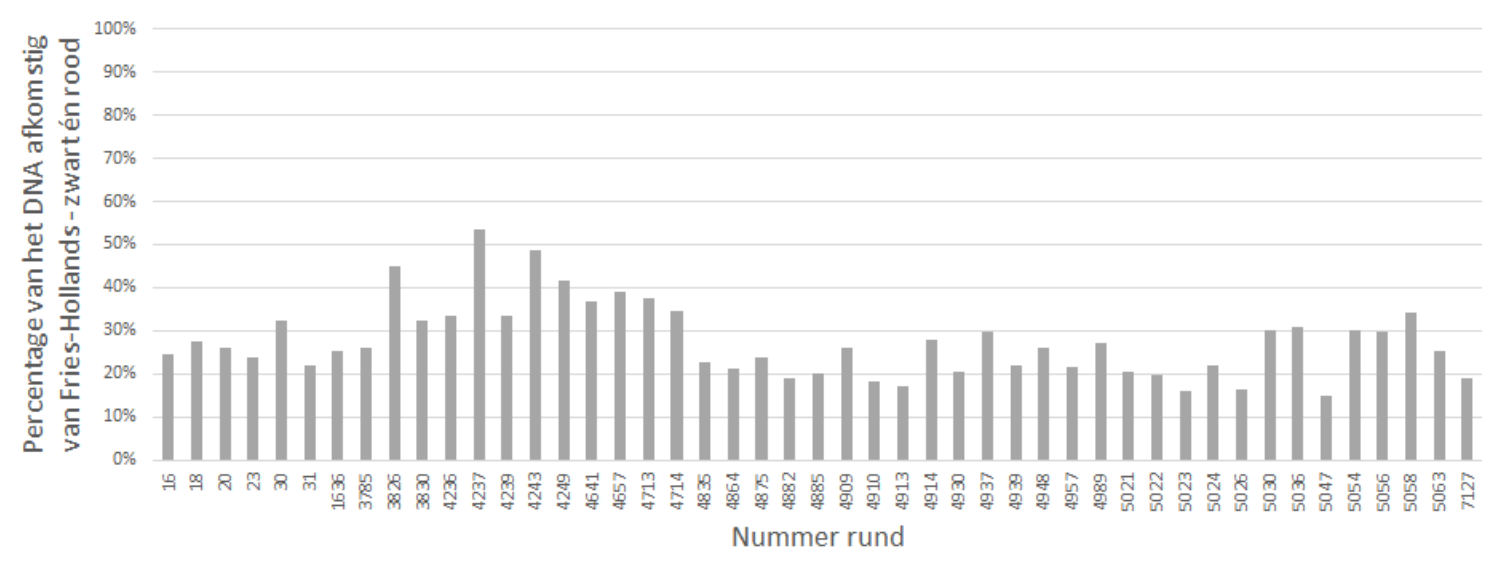

Figuur 2.3 Resultaten van de STRUCTURE analyse waarbij voor elk individueel rund het raspercentage voor Fries-Hollands - zwart én rood is opgeteld en wordt weergegeven.

Opvallend is dat het raspercentage voor Fries-Hollands - zwart én rood van de meer recent geboren runderen (jaar 2016 en 2017; gemiddeld 28,9\%) maar ook de oudere runderen (jaar 2005 en 2007 ; gemiddeld 33,2\%) hoger was ten opzichte van de runderen geboren in de tussenliggende jaren (gemiddeld 22,8\%). Daarbij wel een kleine kanttekening geplaatst: deze observatie is gebaseerd op een beperkt aantal runderen!

\subsection{Samenvatting bevindingen verwantschap met Nederlandse runderrassen}

Om aan te geven met welke oorspronkelijke Nederlandse rassen de veestapel van familie van der Veen verwant is, zijn analyses uitgevoerd waarvan de gedetailleerde resultaten in dit hoofdstuk staan beschreven.

Verwachting vanuit de geschiedenis van de veestapel van familie van der Veen is dat zowel FriesHollands - zwart én rood hebben bijgedragen. De invloed van deze rassen varieert per rund van $14,9 \%$ tot $53,5 \%$, en is gemiddeld $27,5 \%$.

De resultaten laten zien dat de veestapel van familie van der Veen niet samen clustert met een oorspronkelijk Nederlands ras. De veestapel van familie van der Veen omvat een unieke combinatie van genetisch materiaal. Inzetten op het verzamelen van sperma van stieren aanwezig in deze veestapel en embryo's van koeien is een gewenste volgende stap. 


\section{$3 \quad$ Kleurvererving in de veestapel}

In dit hoofdstuk worden de resultaten beschreven met betrekking tot de kleurvererving in de veestapel van familie van der Veen.

\subsection{Kleuren aanwezig in de veestapel}

Kleur van de runderen werd vastgesteld door zowel het stamboek als familie van der Veen. Een overzicht hiervan staat in Tabel 3.1. Verhildersum Femke (NL4704 3785 6) bleek niet gegenotypeerd te zijn, en kon in de kleurvererving analyse niet meegenomen worden.

Tabel 3.1 Kleurbeschrijving van de runderen in de veestapel van familie van der Veen.

\begin{tabular}{lrr} 
Kenmerk & Aantal runderen & Percentage \\
Kleurcode CRV & 13 & $29,3 \%$ \\
\hline AR & 13 & $29,3 \%$ \\
\hline AZ & 2 & $4,3 \%$ \\
\hline RB & 15 & $32,6 \%$ \\
\hline VB & 3 & $6,5 \%$ \\
\hline ZB & & \\
\hline Kleur vastgesteld door & & $4,3 \%$ \\
familie van der Veen & 2 & $19,6 \%$ \\
\hline Bont rood & 9 & $2,2 \%$ \\
\hline Bont vaal donker & 1 & $4,3 \%$ \\
\hline Bont vaal licht & 2 & $21,8 \%$ \\
\hline Bont zwart & 10 & $29,3 \%$ \\
\hline Witrik blauw & 13 & $4,3 \%$ \\
\hline Witrik rood & 2 & $10,9 \%$ \\
\hline Witrik vaal blauw & 5 & $4,3 \%$ \\
\hline Witrik vaal donker & 2 & \\
\hline Witrik zwart & & \\
\hline
\end{tabular}

\subsection{Genetische merkers die bijdragen aan kleurvererving}

In totaal werden genotypes voor 24 genetische merkers aangeleverd, die betrokken zijn bij kleurvererving in runderen. Het aantal unieke merkers was 9 ( $L D \neq 1$, waarbij de genotypes van de ene merker niet identiek zijn aan het genotype van een nabijgelegen merker). Genotypes voor de betreffende genetische merkers (of beter gezegd de mutatie verantwoordelijk voor de kleur) staat in Tabel 3.2 beschreven. Het gen betrokken bij de overerving van zwart/rood is MC1R (BTA18) en bij vaal is PMEL (BTA5), TYRP1 (BTA8) en MITF_2 (BTA22). Meer over de overerving van de kleuren staat beschreven in "3.4 Vergelijking tussen geobserveerde kleur, verwacht en geobserveerd genotype per rund".

Tabel 3.2 Informatie over de gegenotypeerde (unieke, $L D \neq 1$ ) mutaties in genen betrokken bij overerving van zwart/rood en vaal.

\begin{tabular}{|c|c|c|c|c|c|c|c|}
\hline \multirow[b]{2}{*}{ Naam gen } & \multirow[b]{2}{*}{ BTA } & \multirow[b]{2}{*}{ Positie } & \multirow[b]{2}{*}{ Opmerking } & \multicolumn{3}{|c|}{ Genotype } & \multirow[b]{2}{*}{ Allelfreq } \\
\hline & & & & AA & $\mathbf{A B}$ & BB & \\
\hline PMEL_1 & 5 & 57.669 .912 & InDelAlleles & 28 & 16 & 1 & 0,80 \\
\hline PMEL_2 & 5 & 57.669 .926 & & 46 & 0 & 0 & 1 \\
\hline TYRP1 & 8 & 31.711 .945 & & 45 & 0 & 0 & 1 \\
\hline EuroG10K_SNP_MC1R_346 & 18 & 14.757 .898 & & 46 & 0 & 0 & 1 \\
\hline EuroG10K_SNP_MC1R_358 & 18 & 14.757 .910 & & 6 & 10 & 0 & 0,69 \\
\hline EuroG10K_SNP_MC1R_358_R_B & 18 & 14.757 .910 & & 14 & 22 & 10 & 0,54 \\
\hline MC1R & 18 & 14.757 .924 & InDelAlleles & 46 & 0 & 0 & 1 \\
\hline EuroG10K_SNP_AF547663_L & 18 & 14.757 .925 & & 35 & 11 & 0 & 0,88 \\
\hline MITF_2 & 22 & 31.769 .189 & regulatie TYRP1 & 34 & 10 & 1 & 0,87 \\
\hline
\end{tabular}


Daarnaast segregeren witrik (colour-sided; Cs20 op BTA29), bont (spotted; KIT op BTA6) en blauw (roan; KITLG op BTA5) in de veestapel van familie van der Veen. De daadwerkelijke mutaties voor deze genen waren echter niet voor handen (wel dus voor zwart/rood en vaal). In dergelijke situaties kan gebruik worden gemaakt van genetische merker(s) die in de buurt liggen van deze genen. Als dergelijke merkers dichtbij het gen liggen, vertegenwoordigen deze merkers nagenoeg dezelfde informatie als het gen zelf (het principe van linkage disequilibrium, LD). De onderzochte genetische merkers in de buurt van genen verantwoordelijk voor blauw en bont staan vermeld in Tabel 3.3.

Tabel 3.3 Informatie over de gegenotypeerde genetische merkers in de buurt van genen betrokken bij overerving van witrik, bont en blauw.

\begin{tabular}{|c|c|c|c|c|c|c|c|}
\hline Naam genetische merker & BTA & Positie & Opmerking & \multicolumn{3}{|c|}{ Genotype } & Allelfreq \\
\hline Gen: KITLG & 5 & 18.339 .001 & Overerving blauw & & & & \\
\hline BTA-74302-NO-RS & 5 & 18.047 .140 & & 27 & 19 & 0 & 0,79 \\
\hline BTA-74304-NO-RS & 5 & 18.075 .032 & & 18 & 26 & 1 & 0,69 \\
\hline HAPMAP25789-BTA-123396 & 5 & 18.294 .913 & & 15 & 28 & 3 & 0,63 \\
\hline HAPMAP26418-BTA-147132 & 5 & 18.321 .966 & & 45 & 0 & 0 & 1 \\
\hline BTA-72821-NO-RS & 5 & 18.434 .417 & & 46 & 0 & 0 & 1 \\
\hline BTA-72820-NO-RS & 5 & 18.456 .049 & & 45 & 1 & 0 & 0,99 \\
\hline HAPMAP41762-BTA-117570 & 5 & 18.943 .987 & & 40 & 5 & 0 & 0,94 \\
\hline HAPMAP38628-BTA-76690 & 6 & $69,639,884$ & & 31 & 12 & 2 & 0,82 \\
\hline ARS-BFGL-NGS-108820 & 6 & $69,807,027$ & & 25 & 20 & 1 & 0,76 \\
\hline HAPMAP50117-BTA-81807 & 6 & $69,840,434$ & & 26 & 19 & 1 & 0,77 \\
\hline ARS-BFGL-NGS-93633 & 6 & $69,882,331$ & & 43 & 3 & 0 & 0,97 \\
\hline ARS-BFGL-NGS-32371 & 6 & $70,000,724$ & & 18 & 18 & 8 & 0,61 \\
\hline ARS-BFGL-NGS-96402 & 6 & $70,025,545$ & & 26 & 13 & 3 & 0,77 \\
\hline ARS-BFGL-NGS-117236 & 6 & $70,065,213$ & & 16 & 24 & 6 & 0,61 \\
\hline ARS-BFGL-NGS-26116 & 6 & $70,123,449$ & & 45 & 1 & 0 & 0,99 \\
\hline HAPMAP60836-RS29027147 & 6 & $70,209,132$ & & 26 & 17 & 3 & 0,75 \\
\hline HAPMAP54879-RS29017018 & 6 & $70,236,581$ & & 26 & 16 & 3 & 0,76 \\
\hline
\end{tabular}

\subsection{Relaties tussen genotypes (DNA) en fenotypes (kleur)}

Om eenduidig een relatie tussen genotype (het DNA) en fenotype (wat we zien/meten, in dit geval kleur) vast te stellen, is het van belang dat er geen verstrengeling optreedt tussen de verschillende kleuren. Wanneer we naar de veestapel van familie van der Veen kijken, is er sprake van verstrengeling tussen de verschillende kleuren: runderen met een bonte aftekening zijn geen witrik, en witrikken zijn niet bont. Daarnaast hebben alle runderen met een vale kleur ook een bonte aftekening. Verder hebben alle witrikken niet een vale kleur. Een ietwat minder heldere verstrengeling (opgemerkt bij kleurdefiniëring van familie van der Veen) treedt op tussen bont, rood/zwart en witrik: het merendeel $(87,5 \%)$ van de rode runderen is niet bont maar wel witrik (ten opzichte van $50 \%$ van de zwarte runderen). Bij kleurdefiniëring door familie van der Veen valt op dat alle blauwe runderen niet bont zijn, maar wel witrik. Verder is $80 \%$ van de niet-vaal gekleurde runderen rood en $20 \%$ zwart. 
Het gevolg van verstrengeling is bijvoorbeeld dat het gen PMEL(_1) dat betrokken is bij overerving van vaal, ook een effect lijkt te hebben op bont. Zoals vastgesteld hebben alle vale runderen een bonte aftekening. Omdat bont en vaal dus verstrengeld zijn, vinden we een onecht effect van het gen PMEL(_1) op bont.

Relaties tussen genotype en kleur werden statistisch getoetst met een Chi-kwadraat test om na te gaan of de veronderstelde relatie in het licht van de waarnemingen, verworpen dient te worden (zie Tabel 3.4). Wanneer de relatie significant wordt bevonden (de significantie is $\mathbf{0 . 0 5}$ ), lijkt het onaannemelijk dat de gevonden relatie tussen genotype en kleur op toeval berust; de veronderstelde relatie betreft dus een daadwerkelijke relatie tussen genotype en kleur.

Tabel 3.4 Significantie (Chi-kwadraat test) van de relaties tussen genotypes en kleur. Grijs gearceerd: significante relatie tussen genotype en kleur (Chi-kwadraat test $\leq 0.05$ ); roze gearceerd: verwachte relatie tussen genotype en kleur.

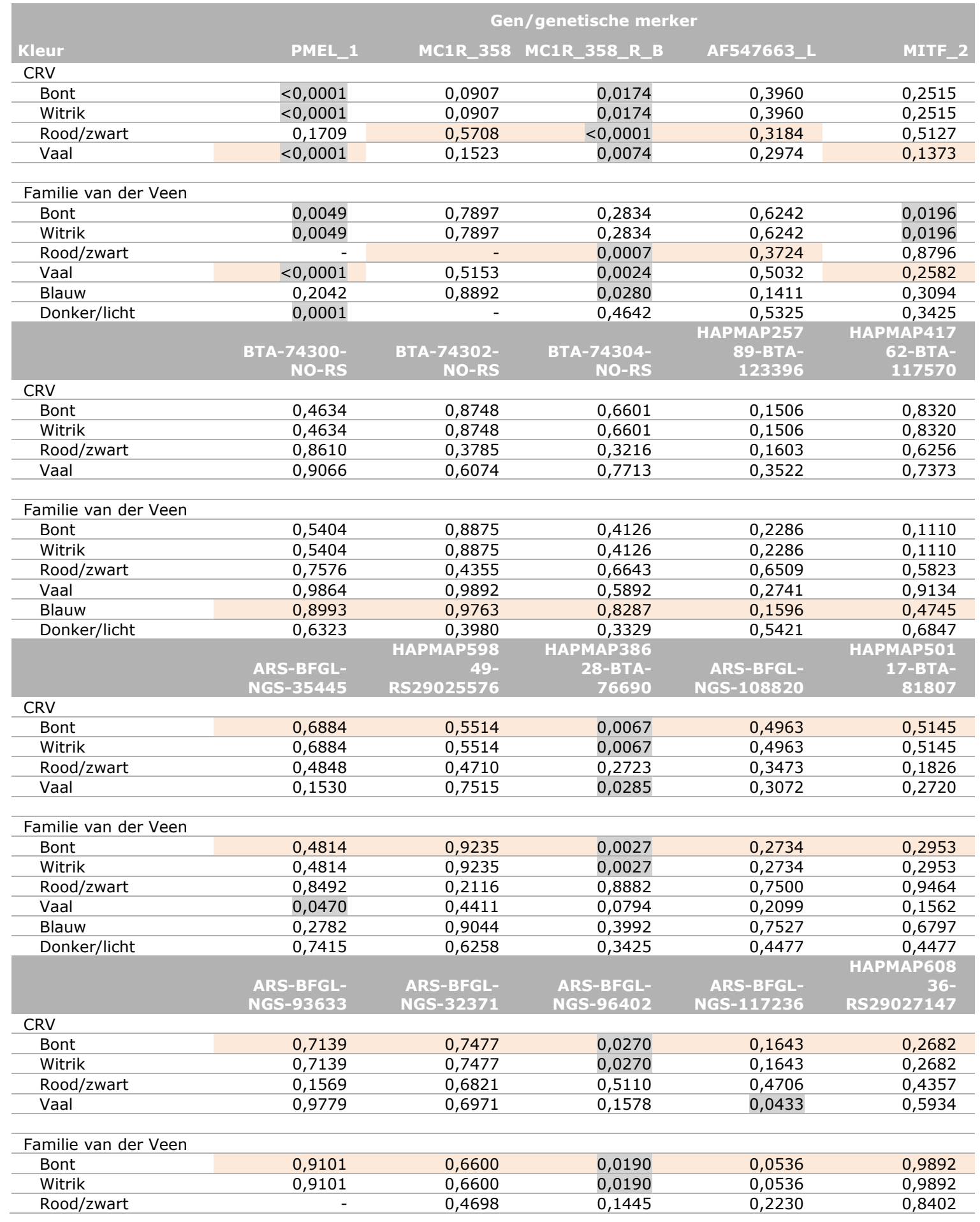




\begin{tabular}{|c|c|c|c|c|c|}
\hline Vaal & 0,8930 & 0,5310 & 0,2536 & 0,0048 & 0,3204 \\
\hline Blauw & 0,0978 & 0,3110 & 0,5827 & 0,3090 & 0,6049 \\
\hline \multirow[t]{3}{*}{ Donker/licht } & 0,7821 & 0,5836 & 0,4878 & 0,4642 & 0,7650 \\
\hline & HAPMAP548 & & HAPMAP445 & & \\
\hline & $\begin{array}{r}79- \\
\text { RS29017018 }\end{array}$ & $\begin{array}{l}\text { ARS-BFGL- } \\
\text { NGS-117001 }\end{array}$ & $\begin{array}{r}12-B T A- \\
107928\end{array}$ & $\begin{array}{l}\text { ARS-BFGL- } \\
\text { NGS-44467 }\end{array}$ & $\begin{array}{l}\text { ARS-BFGL- } \\
\text { NGS-117739 }\end{array}$ \\
\hline \multicolumn{6}{|l|}{ CRV } \\
\hline Bont & 0,1753 & 0,0993 & 0,2826 & 0,1778 & 0,4729 \\
\hline Witrik & 0,1753 & 0,0993 & 0,2826 & 0,1778 & 0,4729 \\
\hline Rood/zwart & 0,4357 & 0,5473 & 0,3428 & 0,5763 & 0,5012 \\
\hline Vaal & 0,4059 & 0,1371 & 0,7740 & 0,7864 & 0,4180 \\
\hline \multicolumn{6}{|c|}{ Familie van der Veen } \\
\hline Bont & 0,9087 & 0,0960 & 0,4241 & 0,4137 & 0,7051 \\
\hline Witrik & 0,9087 & 0,0960 & 0,4241 & 0,4137 & 0,7051 \\
\hline Rood/zwart & 0,8402 & 0,7768 & 0,6223 & 0,4355 & 0,4522 \\
\hline Vaal & 0,1966 & 0,2501 & 0,5203 & 0,5489 & 0,2019 \\
\hline Blauw & 0,6687 & 0,5407 & 0,1779 & 0,7227 & 0,2534 \\
\hline Donker/licht & 0,8062 & 0,2602 & 0,4106 & 0,6997 & 0,5879 \\
\hline
\end{tabular}

Significante relaties (Chi-kwadraat test $\leq 0.05$ ) tussen genotype en kleur werden vastgesteld voor de genetische merkers en kleuren in Tabel 3.5. Voor een groot deel van de testen wordt echter een waarschuwing afgegeven: $50 \%$ van de cellen heeft een aantal van 5 of minder, de Chi-kwadraat test kan mogelijk een niet valide test zijn. In verband met een beperkt aantal runderen (en een beperkt aantal runderen met een bepaalde kleur) waarop de test wordt uitgevoerd, is dit onvermijdelijk. Het beperkte aantal runderen (met een bepaalde kleur) zorgt er waarschijnlijk ook voor dat een aantal verwachte relaties (roze gearceerd) niet significant bevonden worden.

Tabel 3.5 Significante relaties (Chi-kwadraat test $\leq 0.05)$ tussen genotypes en kleur bepaald door CRV en familie van der Veen ( $v d v)$.

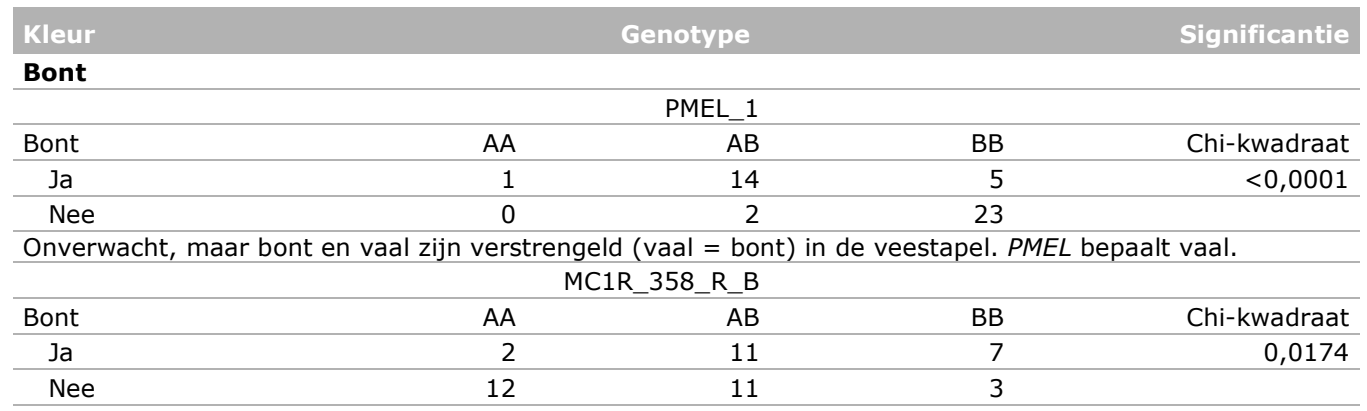

Onverwacht, maar bont en rood/zwart zijn deels verstrengeld (rood $\neq$ bont) in de veestapel. MC1R bepaalt mede rood/zwart.

\begin{tabular}{|c|c|c|c|c|}
\hline \multicolumn{5}{|c|}{ PMEL_1 } \\
\hline Bont - vdv & $A A$ & $A B$ & BB & Chi-kwadraat \\
\hline $\mathrm{Ja}$ & 1 & 9 & 4 & 0,0049 \\
\hline Nee & 0 & 7 & 24 & \\
\hline
\end{tabular}

Onverwacht, maar bont en vaal zijn verstrengeld (vaal = bont) in de veestapel. PMEL bepaalt vaal.

\begin{tabular}{crrrr}
\hline & \multicolumn{1}{c}{ MITF_2 } & BB & Chi-kwadraat \\
\hline Bont $-v d v$ & AA & AB & 7 & 0,0196 \\
\hline Nee & 1 & 6 & 27 &
\end{tabular}

Onverwacht, maar bont en vaal zijn verstrengeld (vaal = bont) in de veestapel. MITF/TYRP1 bepaalt vaal.

\begin{tabular}{crrrr}
\hline Bont & HAPMAP38628-BTA-76690 & BB & Chi-kwadraat \\
\hline Ja & AA & AB & 9 & 0,0067 \\
\hline Nee & 9 & 9 & 0 & \\
\hline
\end{tabular}

Verwacht. HAPMAP38628-BTA-76690 ligt in de buurt van het gen KIT dat bont bepaalt.

\begin{tabular}{crrrr}
\hline \multicolumn{5}{c}{ HAPMAP38628-BTA-76690 } \\
\hline Bont - vdv & AA & AB & BB & Chi-kwadraat \\
\hline Ja & 5 & 7 & 2 & 0,0027 \\
\hline Nee & 26 & 5 & 0 & \\
\hline
\end{tabular}

Verwacht. HAPMAP38628-BTA-76690 ligt in de buurt van het gen $K I T$ dat bont bepaalt.

\begin{tabular}{crrrr}
\hline \multicolumn{5}{c}{ ARS-BFGL-NGS-96402 } \\
\hline Bont & AA & AB & BB & Chi-kwadraat \\
\hline Ja & 8 & 8 & 3 & 0,0027 \\
\hline Nee & 18 & 5 & 0 & \\
\hline
\end{tabular}

Verwacht. ARS-BFGL-NGS-96402 ligt in de buurt van het gen KIT dat bont bepaalt.

\begin{tabular}{crrrr}
\hline \multicolumn{5}{c}{ ARS-BFGL-NGS-96402 } \\
\hline Bont - vdv & AA & AB & BB & Chi-kwadraat \\
\hline Ja & 4 & 7 & 2 & 0,0190 \\
\hline Nee & 22 & 6 & 1 & \\
\hline
\end{tabular}




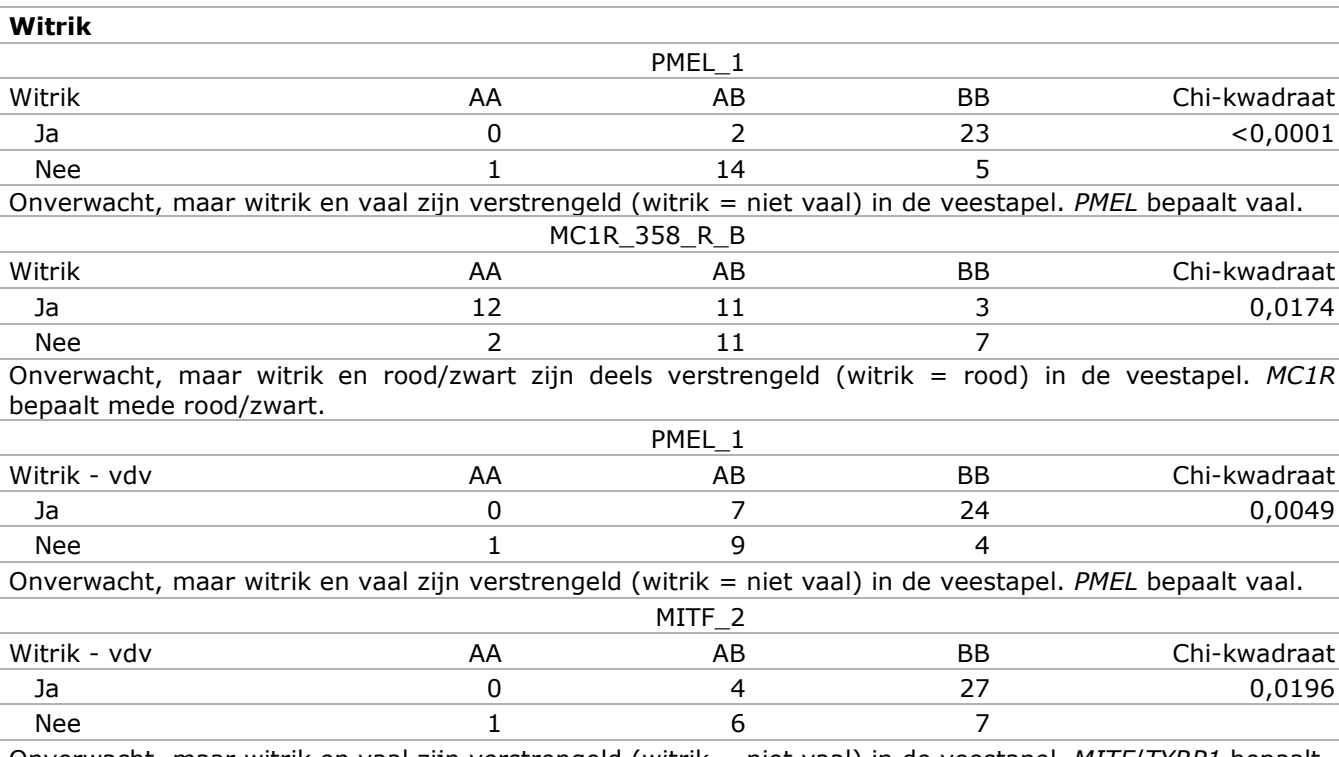

Onverwacht, maar witrik en vaal zijn verstrengeld (witrik = niet vaal) in de veestapel. MITF/TYRP1 bepaalt vaal.

\begin{tabular}{crrrr}
\hline \multicolumn{5}{c}{ HAPMAP38628-BTA-76690 } \\
\hline Witrik & AA & AB & BB & Chi-kwadraat \\
\hline Ja & 22 & 3 & 0 & 0,0067 \\
\hline Nee & 9 & 9 & 2 &
\end{tabular}

Bont is niet witrik en witrikken zijn niet bont in de veestapel. HAPMAP38628-BTA-76690 ligt in de buurt van het gen KIT dat bont bepaalt.

\begin{tabular}{lrrrr}
\hline \multicolumn{5}{c}{ HAPMAP38628-BTA-76690 } \\
Witrik - vdv & AA & AB & BB & Chi-kwadraat \\
Ja & 26 & 5 & 0 & 0,0027 \\
Nee & 5 & 7 & 2 &
\end{tabular}

Bont is niet witrik en witrikken zijn niet bont in de veestapel. HAPMAP38628-BTA-76690 ligt in de buurt van het gen KIT dat bont bepaalt.

\begin{tabular}{|c|c|c|c|c|}
\hline \multicolumn{5}{|c|}{ ARS-BFGL-NGS-96402 } \\
\hline Witrik & AA & $A B$ & BB & Chi-kwadraat \\
\hline $\mathrm{Ja}$ & 18 & 5 & 0 & 0,0027 \\
\hline Nee & 8 & 8 & 3 & \\
\hline
\end{tabular}

Bont is niet witrik en witrikken zijn niet bont in de veestapel. ARS-BFGL-NGS-96402 ligt in de buurt van het gen KIT dat bont bepaalt.

\begin{tabular}{lrrrr} 
& \multicolumn{4}{c}{ ARS-BFGL-NGS-96402 } \\
Witrik - vdv & AA & AB & BB & Chi-kwadraat \\
\hline Ja & 22 & 6 & 1 & 0,0190 \\
\hline Nee & 4 & 7 & 2 & \\
\hline
\end{tabular}

Bont is niet witrik en witrikken zijn niet bont in de veestapel. ARS-BFGL-NGS-96402 ligt in de buurt van het gen $K I T$ dat bont bepaalt.

\begin{tabular}{|c|c|c|c|c|}
\hline \multicolumn{5}{|l|}{ Vaal } \\
\hline \multicolumn{5}{|c|}{ PMEL_1 } \\
\hline Vaal & $A A$ & $A B$ & BB & Chi-kwadraat \\
\hline $\mathrm{Ja}$ & 1 & 14 & 0 & $<0,0001$ \\
\hline Nee & 0 & 2 & 28 & \\
\hline \multicolumn{5}{|c|}{ Verwacht. PMEL bepaalt vaal. } \\
\hline \multicolumn{5}{|c|}{ MC1R_358_R_B } \\
\hline Vaal & $A A$ & $A B$ & BB & Chi-kwadraat \\
\hline $\mathrm{Ja}$ & 0 & 10 & 5 & 0,0074 \\
\hline Nee & 14 & 12 & 5 & \\
\hline \multicolumn{5}{|c|}{$80 \%$ van de vaal gekleurde runderen in de veestapel is rood ( $20 \%$ zwart), deels verstrengeling. } \\
\hline \multicolumn{5}{|c|}{ PMEL_1 } \\
\hline Vaal - vdv & AA & $A B$ & BB & Chi-kwadraat \\
\hline $\mathrm{Ja}$ & 1 & 16 & 0 & $<0,0001$ \\
\hline Nee & 0 & 0 & 28 & \\
\hline \multicolumn{5}{|c|}{ Verwacht. PMEL bepaalt vaal. } \\
\hline \multicolumn{5}{|c|}{ MC1R_358_R_B } \\
\hline Vaal - vdv & $A A$ & $A B$ & BB & Chi-kwadraat \\
\hline $\mathrm{Ja}$ & 0 & 11 & 6 & 0,0024 \\
\hline Nee & 14 & 11 & 4 & \\
\hline
\end{tabular}

$80 \%$ van de vaal gekleurde runderen in de veestapel is rood ( $20 \%$ zwart), deels verstrengeling.

\begin{tabular}{rrrrr}
\hline \multicolumn{5}{c}{ HAPMAP38628-BTA-76690 } \\
Vaal & AA & AB & BB & Chi-kwadraat \\
\hline Ja & 7 & 6 & 2 & 0,0285 \\
\hline
\end{tabular}


Onverwacht, maar bont en vaal zijn verstrengeld (vaal = bont) in de veestapel. HAPMAP38628-BTA-76690 ligt in de buurt van het gen KIT dat bont bepaald.

\begin{tabular}{lrrrr}
\hline \multicolumn{5}{c}{ ARS-BFGL-NGS-35445 } \\
\hline Vaal - vdv & AA & AB & BB & Chi-kwadraat \\
\hline Ja & 1 & 10 & 5 & 0,0470 \\
\hline Nee & 10 & 14 & 3 &
\end{tabular}

Onverwacht, maar bont en vaal zijn verstrengeld (vaal = bont) in de veestapel. ARS-BFGL-NGS-35445 ligt in de buurt van het gen KIT dat bont bepaald.

\begin{tabular}{crrrr}
\hline \multicolumn{5}{c}{ ARS-BFGL-NGS-117236 } \\
Vaal & AA & AB & BB & Chi-kwadraat \\
\hline Ja & 9 & 5 & 1 & 0,0433 \\
\hline Nee & 7 & 19 & 5 & \\
\hline
\end{tabular}

Onverwacht, maar bont en vaal zijn verstrengeld (vaal = bont) in de veestapel. ARS-BFGL-NGS-117236 ligt in de buurt van het gen KIT dat bont bepaald.

\begin{tabular}{lrrrr}
\hline \multicolumn{7}{c}{ ARS-BFGL-NGS-117236 } \\
\hline Vaal - vdv & AA & AB & BB & Chi-kwadraat \\
\hline Ja & 11 & 5 & 1 & 0,0048 \\
\hline Nee & 5 & 19 & 5 &
\end{tabular}

Onverwacht, maar bont en vaal zijn verstrengeld (vaal = bont) in de veestapel. ARS-BFGL-NGS-117236 ligt in de buurt van het gen KIT dat bont bepaald.

\begin{tabular}{|c|c|c|c|c|}
\hline \multicolumn{5}{|l|}{ Rood/zwart } \\
\hline \multicolumn{5}{|c|}{ MC1R_358_R_B } \\
\hline Rood/zwart & $A A$ & $A B$ & BB & Chi-kwadraat \\
\hline Rood & 14 & 1 & 0 & $<0,0001$ \\
\hline Zwart & 0 & 11 & 5 & \\
\hline \multicolumn{5}{|c|}{ Verwacht. MC1R bepaalt mede rood/zwart. } \\
\hline \multicolumn{5}{|c|}{ MC1R_358_R_B } \\
\hline Rood/zwart - vdv & AA & $A B$ & BB & Chi-kwadraat \\
\hline Rood & 14 & 1 & 0 & 0,0007 \\
\hline Zwart & 0 & 3 & 1 & \\
\hline
\end{tabular}

Verwacht. MC1R bepaald rood/zwart.

\begin{tabular}{|c|c|c|c|c|}
\hline Blauw & & & & \\
\hline & & R_B & & \\
\hline Blauw - vdv & $\mathrm{AA}$ & $A B$ & BB & Chi-kwadraat \\
\hline $\mathrm{Ja}$ & 0 & 8 & 4 & 0,0280 \\
\hline Nee & 14 & 14 & 6 & \\
\hline
\end{tabular}

Onverwacht, maar blauw $=$ rood in de veestapel. $M C 1 R$ bepaald rood/zwart.

\begin{tabular}{lrrrr}
\hline \multicolumn{5}{c}{ HAPMAP25789-BTA-123396 } \\
\hline Blauw - vdv & AA & AB & BB & Chi-kwadraat \\
\hline Ja & 2 & 10 & 0 & 0,1596 \\
\hline Nee & 13 & 18 & 3 & \\
\hline
\end{tabular}

Verwacht. HAPMAP25789-BTA-123396 heeft variatie en ligt het dichts in de buurt van het gen KITLG dat blauw bepaalt.

\begin{tabular}{|c|c|c|c|c|}
\hline \multicolumn{5}{|l|}{ Donker/licht } \\
\hline \multicolumn{5}{|c|}{ PMEL_1 } \\
\hline Donker/licht - vdv & $A A$ & $A B$ & $\mathrm{BB}$ & Chi-kwadraat \\
\hline Donker & 0 & 14 & 0 & 0,0001 \\
\hline Licht & 1 & 0 & 0 & \\
\hline
\end{tabular}

Vaal, bont en witrik zijn duidelijk verstrengeld in de veestapel van familie van der Veen: runderen met een bonte aftekening zijn geen witrik, witrikken zijn niet bont, alle runderen met een vale kleur hebben ook een bonte aftekening en verder hebben alle witrikken in de veestapel van familie van der Veen niet een vale kleur. In de gevonden significante relaties tussen genotype en kleur komt deze verstrengeling helder naar voren.

De kleur vaal (zowel bepaald door CRV als door familie van der Veen) is het meest significant geassocieerd met PMEL_1 (gen voor vaal). De kleur rood/zwart (zowel bepaald door CRV als door familie van der Veen) is het meest significant geassocieerd met MC1R_358_R_B (gen voor rood/zwart). De kleur blauw (bepaald door familie van der Veen) is met meest geassocieerd met HAPMAP25789-BTA-123396 (in de buurt van het gen voor blauw), maar niet significant. De kleur bont (bepaald door familie van der Veen) is het meest significant geassocieerd met HAPMAP38628-BTA76690 (in de buurt van het gen voor bont). 
De kleur bont en witrik (bepaald door CRV) is het meest significant geassocieerd met PMEL_1, door verstrengeling tussen bont, witrik en vaal, daar PMEL vaal bepaalt. De kleur witrik (bepaald door familie van der Veen) is het meest significant geassocieerd met HAPMAP38628-BTA-76690 (in de buurt van het gen voor bont), door verstrengeling tussen witrik en bont, daar HAPMAP38628-BTA76690 in de buurt van KIT ligt dat bont bepaalt.

\subsection{Vergelijking tussen geobserveerde kleur, verwacht en geobserveerd genotype per rund}

Op basis van de geobserveerde kleur van de runderen kan voorspeld worden wat het genotype is voor een gen. Het verwachte genotype werd vergeleken met het geobserveerde genotype om te kijken of dit in overeenstemming is. Het verwachte genotype werd verkregen uit het lijvige verslag genaamd 'Behoud de witrik voor Nederland' (Boschma \& van der Veen, 2009), het geobserveerde genotype via het DNA-onderzoek uitgevoerd in Luik, België.

De kleuren aanwezig in de veestapel van familie van der Veen worden bepaald door een aantal genen. Zoals beschreven in Boschma \& van der Veen (2009) zijn dit de volgende genen, of loci op het DNA:

Extension locus voor de basiskleur $(M C 1 R)$ :

- $\quad$ Ed/Ed of Ed/e is zwart

- $\quad$ e/e is rood

Verdunning van de basiskleur, genaamd Dilution (PMEL):

- $\quad D / D$ is lichtvaal

- $\quad D / d^{+}$is donkervaal

- $\quad \mathrm{d}^{+} / \mathrm{d}^{+}$is niet vaal

Schimmel, blauw of roan kleur (KITLG):

- $R / R$ is wit

- $R / r^{+}$is witte en gepigmenteerde haren komen vermengd voor

- $\quad r^{+} / r^{+}$is witte en gepigmenteerde haren zijn van elkaar gescheiden

Witte patronen, ook wel spotting genoemd $(K I T)$;

- $S^{P} / S^{P}, S^{P} / S$ of $S^{P} / S$ is een 'line back'

- $\quad \mathrm{S} / \mathrm{S}$ of $\mathrm{S} / \mathrm{s}$ is eenkleurig

- $\quad \mathrm{s} / \mathrm{s}$ is bont

Colour-sidedness of wel witrik (Cs20):

- $\quad \mathrm{Cs} / \mathrm{Cs}$ is wit met gepigmenteerde oren en mond en licht pigment op de zijden, bekend als 'dubbele witrik'

- $\mathrm{Cs} / \mathrm{Cs}^{+}$is een witrik

- $\mathrm{Cs}^{+} / \mathrm{Cs}^{+}$is geen witrik

Omdat alleen voor vaal en rood/zwart de daadwerkelijke mutatie gegenotypeerd was, kunnen er alleen harde uitspraken gedaan worden met betrekking tot deze genen en geobserveerde kleur. Een gedetailleerd overzicht is te vinden in Bijlage 1. De aan- of afwezigheid van vaal kwam overeen met het DNA. De geobserveerde kleur (zwart of rood) kwam overeen met het DNA, behalve voor één rund: Niko 215 (NL 73065023 2) zou op basis van zijn genotype (Ed/e) niet rood kunnen zijn. Het DNA was echter van onvoldoende kwaliteit waardoor de kans groot is dat dit genotype een genotyperingsfoutje betreft, de geobserveerde kleur is daadwerkelijk rood.

Met betrekking tot witrik, bont en blauw konden er geen harde uitspraken worden gedaan. Voor witrik was er geen locus tot onze beschikking. De genetische merkers in de buurt van KITGL waren niet voorspellend genoeg voor de blauwe kleur. Voor de kleur bont waren de genetische merkers in de 
buurt van KIT iets meer voorspellend, maar nog steeds niet voorspellend genoeg om een uitspraak te kunnen doen.

\subsection{Samenvatting bevindingen kleurvererving in de veestapel}

Het verwachte genotype op basis van de geobserveerde kleur kwam overeen met de geobserveerde genotypering voor de basiskleur rood/zwart, behalve voor één rund, en de aan- of afwezigheid van de vaal kleur. Voor deze kleuren kon de daadwerkelijke mutatie die de kleur veroorzaakt, bekeken worden.

Voor de kleuren witrik, bont en blauw konden er geen harde uitspraken worden gedaan, omdat de daadwerkelijke mutatie niet gegenotypeerd was.

Door gerichte fokkerij in de veestapel van familie van der Veen zijn in Nederland zeldzame kleuren en aftekening bij elkaar gebracht. De bijzondere, van beperkte omvang zijnde veestapel heeft daarmee unieke combinaties van zeldzame allelen en genotypes. Goed om veilig te stellen voor de toekomst! 


\section{$4 \quad$ Vaststellen familiebanden}

Met behulp van genotypes kunnen familiebanden tussen individuen worden geïdentificeerd. In dit hoofdstuk worden de resultaten beschreven met betrekking tot het vaststellen van familiebanden in de veestapel van familie van der Veen op basis van het principe van tegengestelde homozygoten.

\subsection{Het principe van tegengestelde homozygoten}

Het principe van tegengestelde homozygoten is gebruikt om familiebanden tussen runderen in de veestapel van familie van der Veen vast te stellen. Dit principe berust op het feit dat een nakomeling bijvoorbeeld voor een genetische merker nooit het genotype "AA" kan hebben, wanneer een ouder het genotype "GG" heeft, aangezien deze ouder per definitie een " $G$ " zal doorgeven aan de nakomeling (zie Figuur 4.1). Daarvoor zijn alle genetische merkers tussen twee individuen met elkaar vergeleken. Het aantal tegengestelde homozygoten tussen ouder en nakomeling zou zeer beperkt moeten zijn, maar niet nul (door genotyperingsfoutjes die kunnen voorkomen). Daarnaast geldt, hoe nauwer de familieband, des te minder tegengestelde homozygoten, omdat het DNA van meer verwante individuen meer op elkaar lijkt.

Alle runderen zijn met elkaar vergeleken voor alle genetische merkers. Het aantal tegengestelde homozygoten is vastgesteld met een script ontwikkeld door dr. B.J. Hayes en beschreven in een wetenschappelijk artikel (Hayes, 2011).
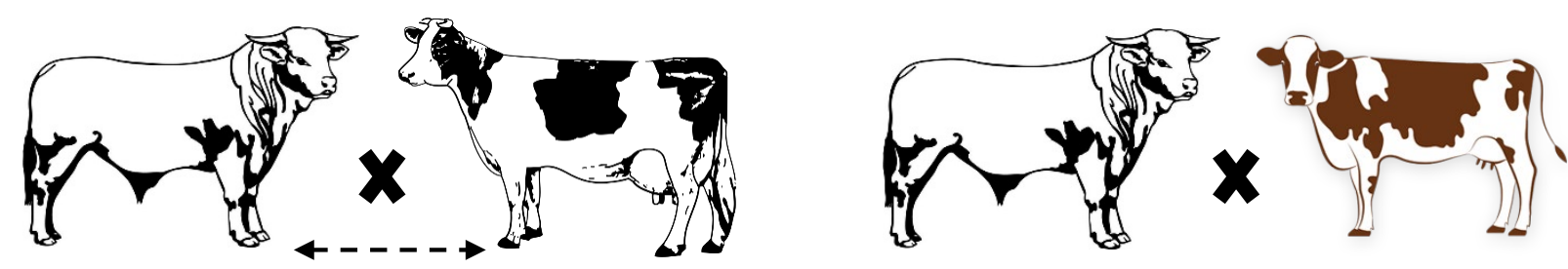

AG

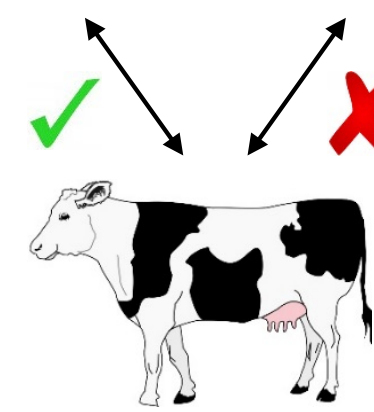

$\underline{A A}$
GG

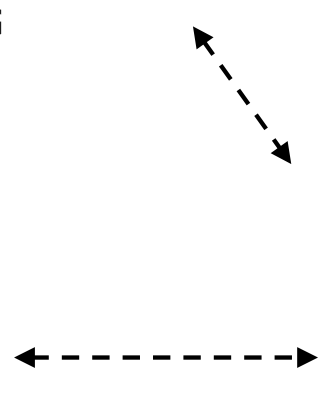

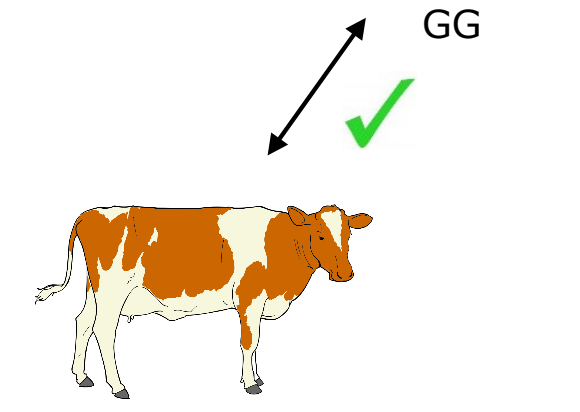

AG

In bovenstaand voorbeeld wordt een tegengesteld homozygoot genotype geobserveerd (GG versus AA) tussen moeder en dochter. Dit duidt op een fout, aangezien de dochter een $\mathrm{G}$ allel van haar moeder had moeten erven. Wanneer een dergelijk tegengesteld homozygoot genotype voor veel van de genetische merkers wordt geobserveerd tussen moeder en dochter, dan duidt dit op een foutief vastgestelde moederdochter relatie.

Ook tussen andere runderen kan het aantal tegengesteld homozygoot genotypes worden vastgesteld (de gestippelde pijlen). Echter, een uitspraak over de relatie tussen dergelijke runderen kan op basis van het principe van tegengestelde homozygoot genotypes niet zo stellig worden bepaald als voor een ouder-nakomeling relatie.

Figur 4.1 Toelichting op het principe van tegengestelde homozygoten. 


\subsection{Ouder-nakomeling relaties}

In Tabel 4.1 staan, door een zeer beperkt aantal tegengestelde homozygoten, op basis van DNA geverifieerde moeder-nakomeling relaties.

Tabel 4.1 Op basis van DNA geverifieerde moeder-nakomeling combinaties.

\begin{tabular}{|c|c|c|c|c|}
\hline Dier 1 & Dier 2 & Aantal tegengestelde homozygoten & Naam dier 1 & Naam moeder \\
\hline 5063 & 4957 & 3 & Nienke 315 & Nienke 215 \\
\hline 31 & 4930 & 5 & Andrieske 23 & Andrieske 3 \\
\hline 18 & 4937 & 9 & Diana 16 & Diana 15 \\
\hline 4989 & 1636 & 11 & Wegtertje 436 & Wegtertje $=$ Wegtertje 36 \\
\hline 5022 & 4882 & 11 & Nienke 415 & Nienke 115 \\
\hline 4910 & 1636 & 12 & Wegtertje 236 & Wegtertje $=$ Wegtertje 36 \\
\hline 4937 & 4714 & 12 & Diana 15 & Diana 5 \\
\hline 4957 & 4882 & 12 & Nienke 215 & Nienke 115 \\
\hline 5054 & 4713 & 12 & Mieneke 343 & Minneke 43 \\
\hline 5026 & 4910 & 13 & Wegtertje 336 & Wegtertje 236 \\
\hline 23 & 4948 & 19 & Femme 2 & Femke 2 \\
\hline 5058 & 4657 & 32 & Mieneke 125 & Mieneke 124 \\
\hline 4948 & 3785 & 39 & Femke 2 & Verhil Femke \\
\hline 4885 & 4657 & 41 & Mieneke 224 & Mieneke 124 \\
\hline 4914 & 4657 & 42 & Mieneke 324 & Mieneke 124 \\
\hline
\end{tabular}

Uit deze geverifieerde moeder-nakomeling combinaties kan een aantal moederlijnen op basis van DNA geverifieerd worden (zie Tabel 4.2).

Tabel 4.2 Op basis van DNA geverifieerde moederlijnen.

\begin{tabular}{|c|c|c|}
\hline Moeder & Nakomeling & Nakomeling \\
\hline \multirow[t]{4}{*}{ Nienke 115} & Nienke 116 & \\
\hline & Nienke 215 & Nienke 315 \\
\hline & & Niko 215 \\
\hline & Nienke 415 & \\
\hline Andrieske 3 & Andrieske 23 & \\
\hline \multirow[t]{2}{*}{ Wegtertje $=$ Wegtertje 36} & Wegtertje 236 & Wegtertje 336 \\
\hline & Wegtertje 436 & \\
\hline \multirow[t]{2}{*}{ Minneke 43} & Mieneke 143 & \\
\hline & Mieneke 343 & \\
\hline \multirow[t]{3}{*}{ Mieneke 124} & Mieneke 324 & Mieneke 325 \\
\hline & Mieneke 224 & \\
\hline & Mieneke 125 & \\
\hline \multirow[t]{2}{*}{ Diana 5} & Diana 15 (4937) & Diana 16 \\
\hline & Diana 15 (4875) & \\
\hline Verhil Femke & Femke 2 & Femme 2 \\
\hline Roza 120 & Roza 121 & \\
\hline
\end{tabular}




\subsection{Overige relaties}

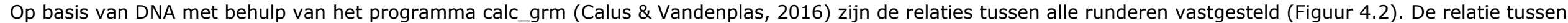
moeder en nakomeling op basis van stambomen is 0,5 . Een dergelijk getal wordt ook verwacht wanneer de relatie tussen moeder en nakomeling op basis van DNA wordt uitgerekend. De 21 moeder-nakomeling combinaties worden wederom geïdentificeerd (Figuur 4.2). Voor half-zussen wordt een relatie van 0,25 verwacht. Op basis van wat er bekend is qua afstamming, zijn een aantal half-zussen aannemelijk en een aantal vastgestelde relaties op basis van DNA onverwacht.

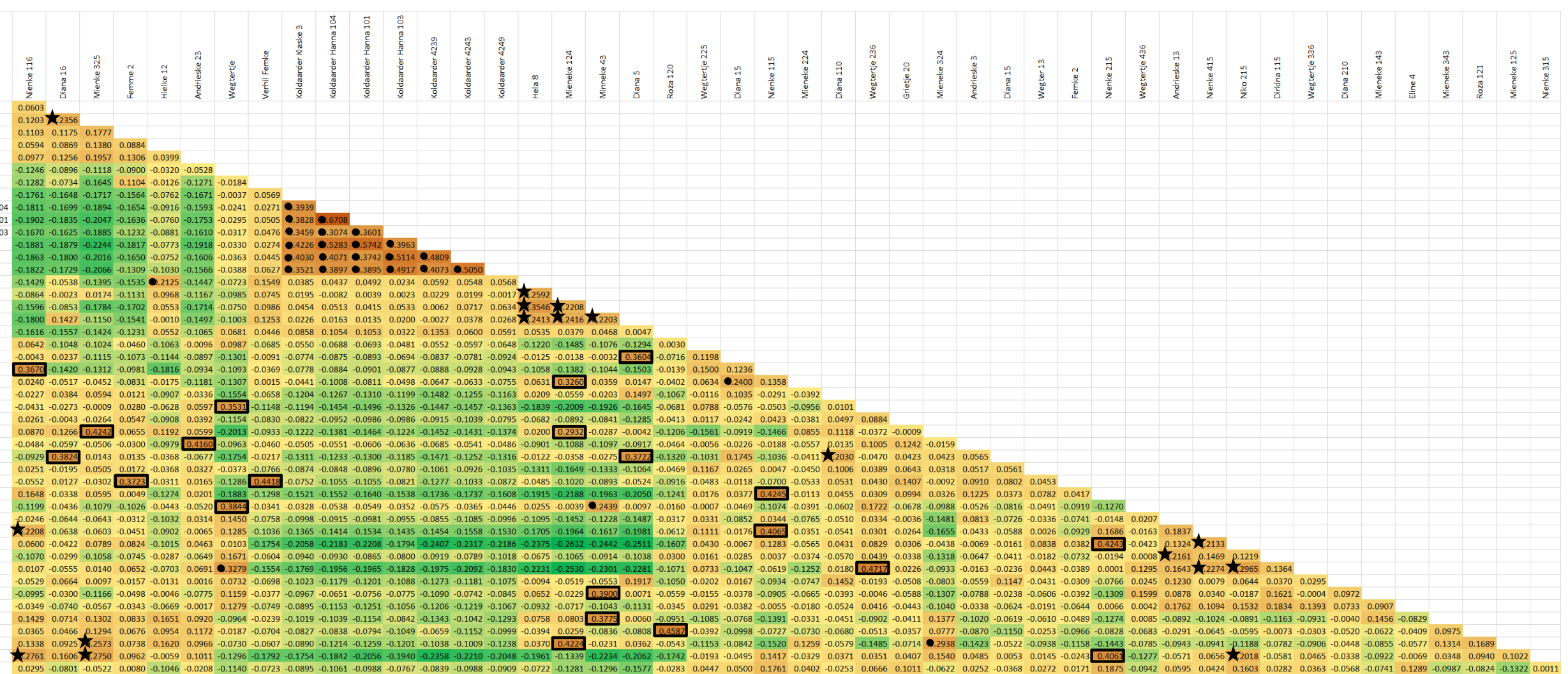

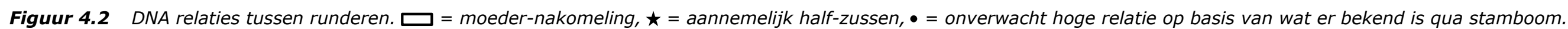




\subsection{Samenvatting bevindingen vaststellen familiebanden}

Op basis van DNA zijn alle moeder-nakomeling combinaties die bekend zijn, geïdentificeerd en daarmee zijn de diverse moederlijnen aanwezig in de veestapel van familie van der Veen geverifieerd met DNA.

Andere familiebanden werden tevens inzichtelijk gemaakt met behulp van DNA. Hierbij werden wederom alle moeder-nakomeling combinaties geverifieerd. In verband met incomplete stamboomgegevens, kunnen er geen harde uitspraken gedaan worden over de andere familiebanden. Een redelijk aantal maternale en paternale half-zus relaties zijn echter aannemelijk. 


\section{Literatuur}

Boschma, N. and P. van der Veen. 2009. Behoud de witrik voor Nederland. Rapportage projectnummer 7, in opdracht van Stichting "de Witrik", Lelystad, 27-11-2009.

Calus, M.P.L. and J. Vandenplas. 2016. Calc_grm - a program to compute pedigree, genomic, and combined relationship matrices. ABGC, Wageningen UR Livestock Research

Hayes, B.J. 2011. Technical note: Efficient parentage assignment and pedigree reconstruction with dens single nucleotide polymorphism data. J. Dairy Sci., 94(4), 2114-2117, doi:10.3168/jds.20103896

Hulsegge, B., M. Schoon, J.J. Windig, M. Neuteboom, S.J. Hiemstra and A. Schurink. 2019. Development of a genetic tool for determining breed purity of cattle. Livest. Sci., 223, 60-67, https://doi.org/10.1016/j.livsci.2019.03.002

Pritchard, J.K., M. Stephens and P. Donnelly. 2000. Inference of population structure using multilocus genotype data. Genetics, 155(2), 945-959 
Bijlage 1 Individuele vergelijking tussen geobserveerde kleur, verwacht en geobserveerd genotype per rund
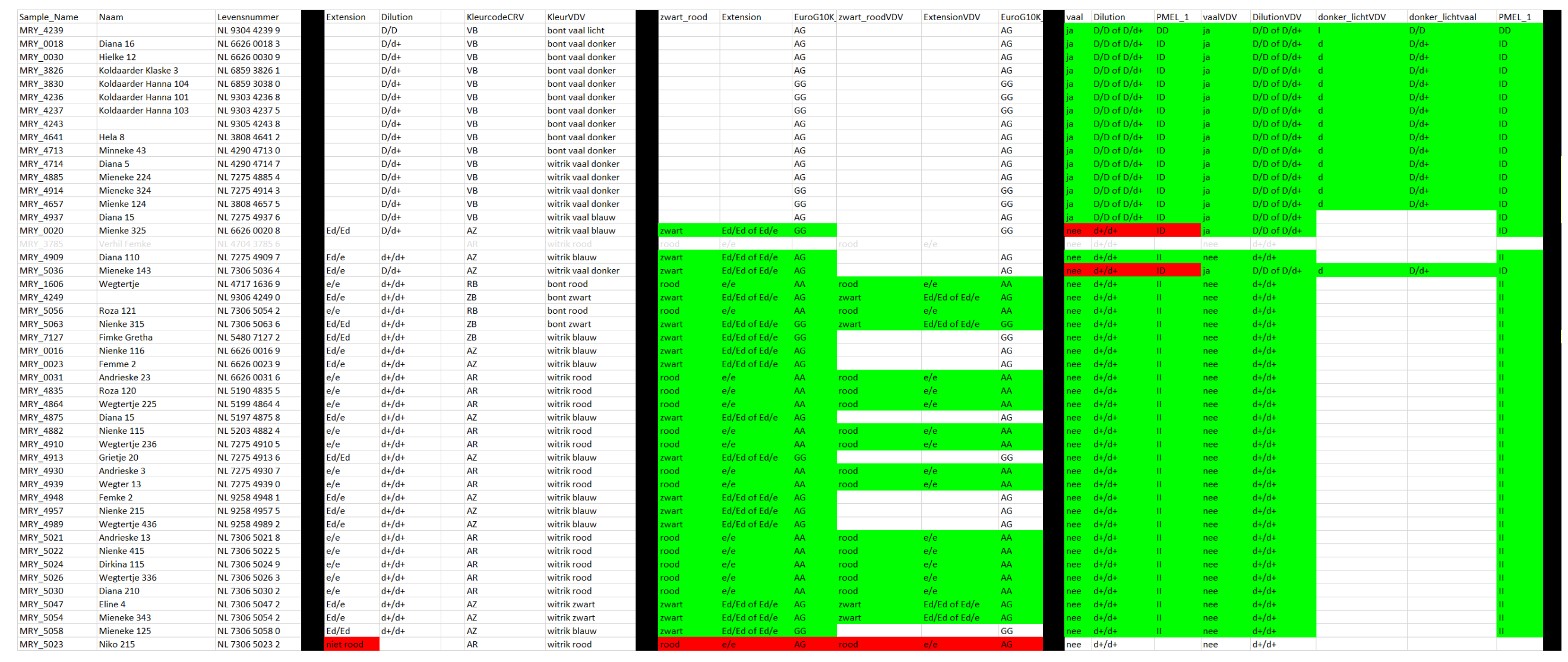

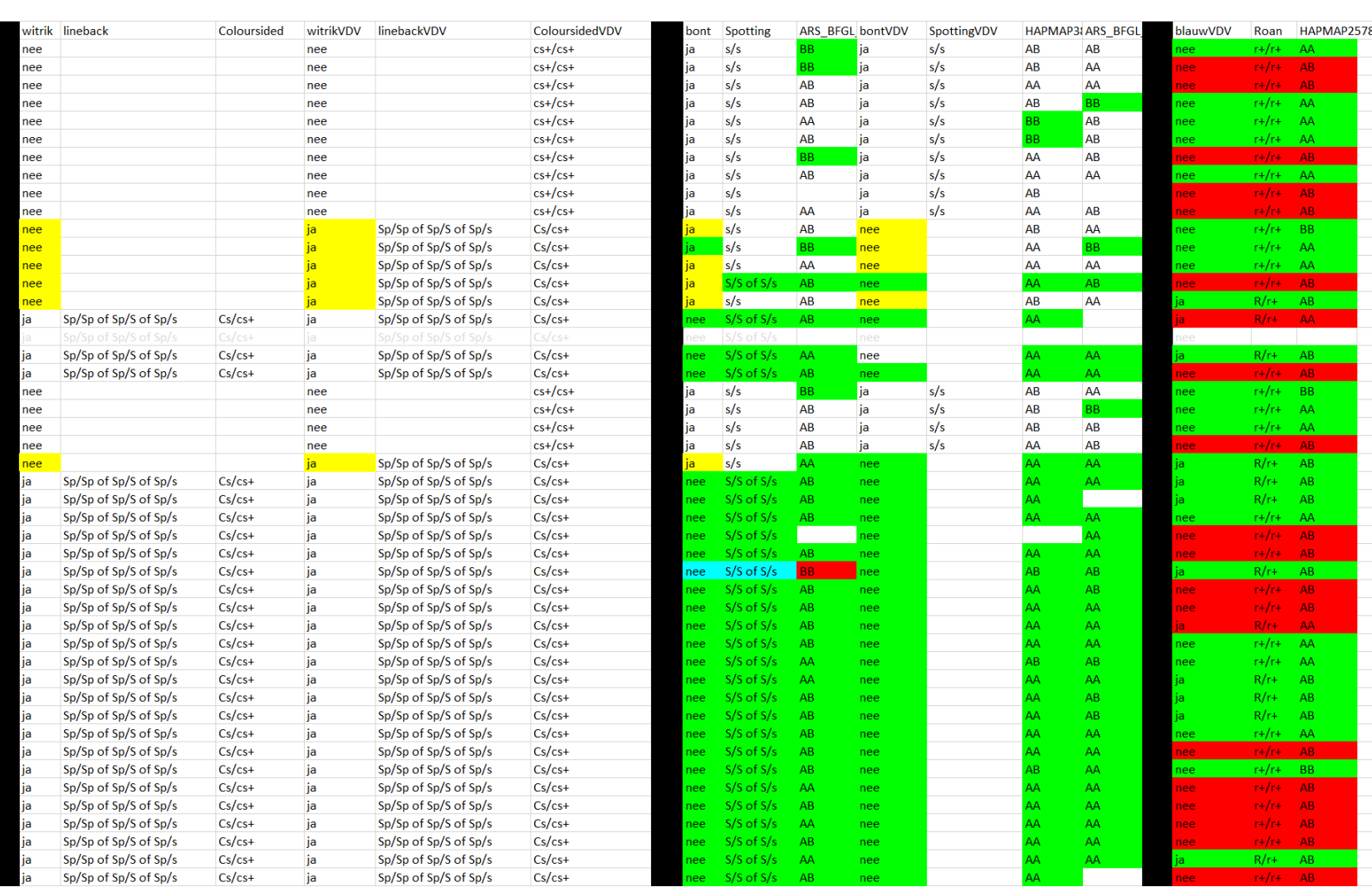



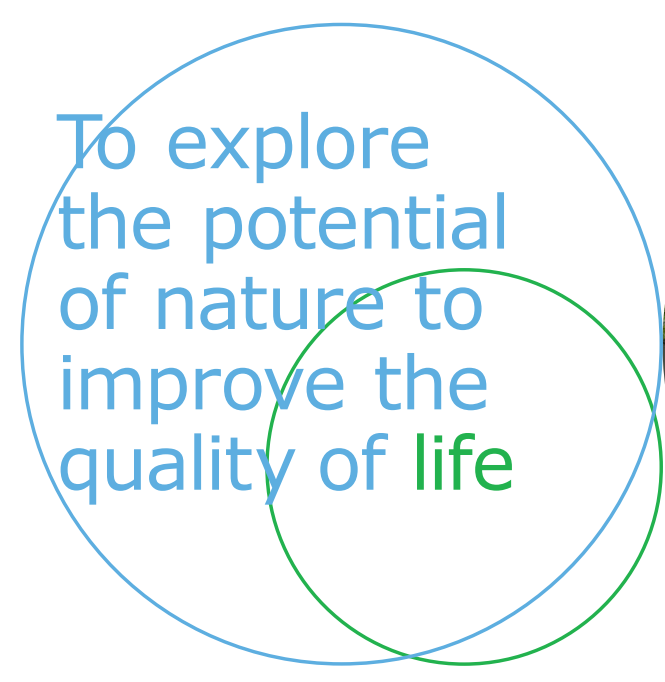

CGN

Postbus 338

6700 AH Wageningen

cgn@wur.nl

www.wur.nl/cgn

Wageningen University \& Research

CGN rapport 43

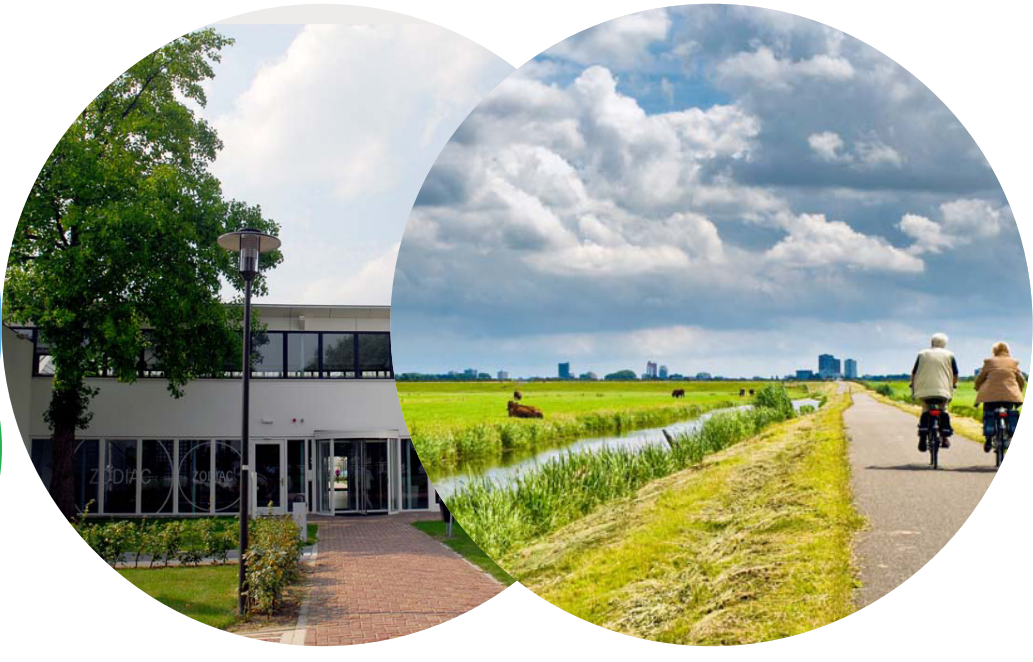

Wageningen Livestock Research ontwikkelt kennis voor een zorgvuldige en renderende veehouderij, vertaalt deze naar praktijkgerichte oplossingen en innovaties, en zorgt voor doorstroming van deze kennis. Onze wetenschappelijke kennis op het gebied van veehouderijsystemen en van voeding, genetica, welzijn en milieu-impact van landbouwhuisdieren integreren we, samen met onze klanten, tot veehouderijconcepten voor de $21 \mathrm{e}$ eeuw.

De missie van Wageningen University \& Research is 'To explore the potential of nature to improve the quality of life'. Binnen Wageningen University \& Research bundelen 9 gespecialiseerde onderzoeksinstituten van Stichting Wageningen Research en Wageningen University hun krachten om bij te dragen aan de oplossing van belangrijke vragen in het domein van gezonde voeding en leefomgeving. Met ongeveer 30 vestigingen, 6.500 medewerkers en 10.000 studenten behoort Wageningen University \& Research wereldwijd tot de aansprekende kennisinstellingen binnen haar domein. De integrale benadering van de vraagstukken en de samenwerking tussen verschillende disciplines vormen het hart van de unieke Wageningen aanpak. 